\title{
A Site-Specific, Weather-Based Disease Regression Model for Sclerotinia Blight of Peanut
}

\author{
D. L. Smith and J. E. Hollowell, Department of Plant Pathology, and T. G. Isleib, Department of Crop Science, \\ North Carolina State University, Raleigh 27695; and B. B. Shew, Department of Plant Pathology, North Carolina \\ State University, Raleigh 27695
}

\begin{abstract}
Smith, D. L., Hollowell, J. E., Isleib, T. G., and Shew, B. B. 2007. A site-specific, weather-based disease regression model for Sclerotinia blight of peanut. Plant Dis. 91:1436-1444.

In North Carolina, losses due to Sclerotinia blight of peanut, caused by the fungus Sclerotinia minor, are an estimated 1 to 4 million dollars annually. In general, peanut (Arachis hypogaea) is very susceptible to Sclerotinia blight, but some partially resistant virginia-type cultivars are available. Up to three fungicide applications per season are necessary to maintain a healthy crop in years highly favorable for disease development. Improved prediction of epidemic initiation and identification of periods when fungicides are not required would increase fungicide efficiency and reduce production costs on resistant and susceptible cultivars. A Sclerotinia blight disease model was developed using regression strategies in an effort to describe the relationships between modeled environmental variables and disease increase. Changes in incremental disease incidence (\% of newly infected plants of the total plant population per plot) for the 2002-2005 growing seasons were statistically transformed and described using 5-day moving averages of modeled site-specific weather variables (localized, mathematical estimations of weather data derived at a remote location) obtained from SkyBit (ZedX, Inc.). Variables in the regression to describe the Sclerotinia blight disease index included: mean relative humidity (linear and quadratic), mean soil temperature (quadratic), maximum air temperature (linear and quadratic), maximum relative humidity (linear and quadratic), minimum air temperature (linear and quadratic), minimum relative humidity (linear and quadratic), and minimum soil temperature (linear and quadratic). The model explained approximately $50 \%$ of the variability in Sclerotinia blight index over 4 years of field research in eight environments. The relationships between weather variables and Sclerotinia blight index were independent of host partial resistance. Linear regression models were used to describe progress of Sclerotinia blight on cultivars and breeding lines with varying levels of partial resistance. Resistance affected the rate of disease progress, but not disease onset. The results of this study will be used to develop site- and cultivar-specific spray advisories for Sclerotinia blight.
\end{abstract}

Additional keyword: groundnut

The soilborne fungus Sclerotinia minor was first identified as a pathogen of peanut (Arachis hypogaea) in Australia in 1948. The first report of the disease in the United States was made in Virginia in 1971 (22). Since then, Sclerotinia blight has become widespread in Virginia and North Carolina, and it also occurs in parts of Oklahoma and Texas (21). Losses in North Carolina are an estimated 1 to 4 million dollars annually (B. Shew, unpublished data).

The mycelium of $S$. minor attacks all parts of peanut plants. Infected leaves and stems initially have a water-soaked appearance. As the disease progresses, signs consisting of white, fluffy masses of mycelium often appear on the surface of colo-

Corresponding author: D. L. Smith

E-mail: dlsmith6@unity.ncsu.edu

Accepted for publication 15 June 2007.

doi:10.1094/PDIS-91-11-1436

(C) 2007 The American Phytopathological Society nized tissue. Later, lesions become bleached and necrotic. Eventually, stems become severely shredded and die. At the end of the growing season, sclerotial densities of ca. 50 sclerotia per $100 \mathrm{~g}$ of soil are possible (22). Research on lettuce isolates suggests that sclerotia undergo a period of dormancy before germination $(8,29)$.

Recommendations for management of Sclerotinia blight include integration of rotation with nonhosts (such as corn, cotton, sorghum, and small grains), planting resistant cultivars, and applications of fungicides (13). Currently, moderately resistant virginia-type cultivars include VA 98R (18) and Perry (10). Because resistance in these cultivars is moderate to low, applications of fungicides often are needed to maintain a healthy crop (13). The first fungicide application typically is made at the first observation of signs or symptoms, with subsequent applications made as directed by the product label. Depending on time of disease onset, up to three fungicide applications may be necessary to provide continuous protection in years highly fa- vorable for disease development (13). Furthermore, the labeled fungicides (fluazinam and boscalid) are protectants and must be applied prior to disease onset for best results $(2,26,27)$. The use of partial resistance and disease forecasting systems can help save fungicide applications, especially in years unfavorable for disease. Improved prediction of epidemic initiation and identification of periods when fungicides are not required can greatly increase efficiency of fungicide use.

Disease advisories based on algorithms of weather thresholds have proven useful in predicting when the fungus would become active $(1,15,20)$. In North Carolina, a Sclerotinia blight advisory was developed based on an algorithm that accounted for rainfall, air temperature, and soil temperature after canopy closure. Fungicide use based on these algorithms provided control comparable to, and in some cases better than, that obtained by the conventional method (1). Research over a period of 16 years confirmed that canopy closure was significant in predicting initial outbreaks of Sclerotinia blight (19). Rainfall, soil temperature, and air temperature were included in the algorithm for the disease advisory. The algorithm has since been modified in Virginia and now uses a 5-day risk index, which is a sum of the five previous daily risk indices. The daily risk index is the product of the environmental index (product of the moisture and soil temperature thresholds) and host index (product of the vine growth and canopy thresholds) (20). Once the 5-day risk index is favorable for disease development, a fungicide application is advised and the index is reset to zero for a 2- to 3-week period based on the protection offered by the applied fungicide. After this period, the 5-day risk index calculations are restarted and fungicides are reapplied when thresholds are again met (15). This advisory (Phipps-Langston advisory) has improved the timing of fungicide application when compared with the traditional method in Virginia peanut production (15). A slightly modified version of the Phipps-Langston advisory is currently in use in North Carolina (13).

The Phipps-Langston advisory used in the Virginia-Carolina peanut production region is not site-specific (localized to a specific field). For some growers, risk calculated by the advisory is based on data 
from automated weather stations that may be several miles away. Rain totals, which are used in the Phipps-Langston advisory, pose a particular problem because scattered thunderstorms are the predominant source of rainfall in the summer. Rainfall recorded at a given weather station may not be representative of conditions even in very close proximity to the station. As an alternative, modeled weather data inputs with no on-site sensors (mathematical estimations of weather variables derived from a remote location) offer several advantages when used with disease advisories (16). No equipment has to be placed in the field and maintained. Weather information can be much more site-specific than has been previously available with networked automated weather stations. Sitespecific disease advisories using modeled weather data have been developed and validated in several other high value crops, including grape and apple (16).

Disease warning models based on relationships between weather parameters and disease outbreaks can use regression approaches as an alternative to risk indices or algorithms. A regression-based warning model was developed to predict outbreaks of brown patch on perennial ryegrass turf (5). Mean relative humidity and minimum air temperature were used in the regression model to predict the environmental favorability (E) for brown patch outbreaks (5). The model predicted all major infection outbreaks over a 3-year span. Reduction in fungicide application was also noted with comparable levels of disease development as compared with a calendar-based application of fungicide (5).

The objective of this research was to develop a multiple regression model describing the relationship between selected modeled, site-specific environmental variables and incidence of Sclerotinia blight on several peanut cultivars and breeding lines. The model will be used to further improve disease advisory systems for Sclerotinia blight in North Carolina.

\section{MATERIALS AND METHODS}

Field studies and design. Ten field studies were conducted in cooperative grower fields during the 2002, 2003, 2004, and 2005 growing seasons. In 2002, the field site was located in Perquimans County, NC. In 2003, two field experiments were planted in Perquimans and Chowan counties, NC. Fields were located in Bertie, Perquimans, and Northampton counties during the 2004 growing season. In 2005, fields were located in Bertie and Northampton counties. In all years, planting was in the month of May (Table 1). Plots consisted of four $91-\mathrm{cm}$ rows and were $7.6 \mathrm{~m}$ long. Planted borders between plots were $3 \mathrm{~m}$ long. At the Perquimans County sites in 2002 and 2003, plots were planted with the cultivars NC 12C (9) or Perry (Table 1). In 2004 (all field sites) the cultivars Gregory (12), VA 98R, Perry, and breeding line N02006 were planted. At the Perquimans County site, 2004, the resistant germplasm line N96076L (11) was also planted (Table 1). In 2005, the cultivars planted at both sites were Gregory, VA 98R, Perry, and the breeding lines N02006 and N03081T (Table 1). Tillage was conventional for all trials with the exception of trials in Northampton County, which were strip-tilled. For all trials, peanuts were planted with a two-row tractor mounted planter set to dispense a minimum of four to five seeds per $0.3 \mathrm{~m}$. Aldicarb (Temik 15G; Bayer Crop Science) at $7.4 \mathrm{~kg} / \mathrm{ha}$ was applied in-furrow at planting for insect control. Standard production practices for peanuts in North Carolina, including appli- cation of fungicides for foliar disease control, were followed throughout the growing season (13). In 2005, foliar fungicide programs used chlorothalonil on the first and last applications of fungicide, with the intermediate fungicide decisions left at the discretion of the individual grower. Chlorothalonil was not included in the foliar fungicide program in 2002, 2003, or 2004 based on previous research indicating its ability to enhance aggressiveness in $S$. minor (7). In all years, leaf spot diseases (caused by the fungi Cercospora arachidicola and Cercosporidium personatum) were adequately managed and no excessive defoliation was noted. Fluazinam (Omega 500F; Syngenta Crop Protection) was applied three times at three rates to establish different levels of disease for concurrent yield loss studies (D. Smith, unpublished data). Spray treatments included a full rate $(0.87 \mathrm{~kg}$ a.i./ha), half rate ( $0.43 \mathrm{~kg}$ a.i./ha), and no fungicide. These experiments were factorial with cultivars (differential levels of partial resistance) and application of three rates of fungicide as the interacting factors. The experimental design for these trials was split-plots with cultivars as whole plots in a randomized complete block design with six replicates and spray applications as subplots.

The field trial in Chowan County in 2003 and one trial in Bertie County in each of 2004 and 2005 included fungicide evaluation trials. In those trials, the cultivar NC-V 11 (30) (susceptible) was planted in plots consisting of four $91-\mathrm{cm}$ rows, 15.2 $\mathrm{m}$ long (Chowan County 2003 and Bertie County 2004) or $7.6 \mathrm{~m}$ long (Bertie County 2005). Planted borders between plots were $3 \mathrm{~m}$ long. Treatments consisted of various sequences and/or rates of the fungicides boscalid (Endura, BASF) or fluazinam (Omega 500F, Syngenta) and no

Table 1. Growing season, location, tillage practice, planting date, date of first rating and duration, digging dates, harvest dates, and cultivars with resistance classifications for all field trials used for the development of the disease model

\begin{tabular}{|c|c|c|c|c|c|c|}
\hline Location $^{\text {a }}$ & Planting date & $\begin{array}{l}\text { Date of first } \\
\quad \text { rating }\end{array}$ & $\begin{array}{c}\text { Rating } \\
\text { duration }\end{array}$ & Digging date & $\begin{array}{l}\text { Harvest } \\
\text { date }\end{array}$ & Cultivar $^{\mathbf{b}}$ \\
\hline \multicolumn{7}{|l|}{2002} \\
\hline Perquimans Co. & 15 May & $12 \mathrm{Jul}$ & 12 weeks & 4 Oct & $11 \mathrm{Oct}$ & NC 12C (VS); Perry (MR) \\
\hline \multicolumn{7}{|l|}{2003} \\
\hline Perquimans Co. & 20 May & $21 \mathrm{Jul}$ & 9 weeks & 9 Oct & 20 Oct & NC 12C (VS); Perry (MR) \\
\hline Chowan Co. (fungicide trial) & 20 May & $21 \mathrm{Jul}$ & 9 weeks & 9 Oct & 20 Oct & NC-V $11(\mathrm{~S})$ \\
\hline \multicolumn{7}{|l|}{2004} \\
\hline Bertie Co. & 10 May & $8 \mathrm{Jul}$ & 10 weeks & $27 \mathrm{Sep}$ & 6 Oct & $\begin{array}{l}\text { Gregory (MS); N02006 (S); } \\
\text { Perry (MR); VA 98R (MS) }\end{array}$ \\
\hline Bertie Co. (fungicide trial) & 10 May & $8 \mathrm{Jul}$ & 10 weeks & 27 Sep & $6 \mathrm{Oct}$ & NC-V $11(\mathrm{~S})$ \\
\hline Perquimans Co. & 18 May & 30 Jun & 11 weeks & $1 \mathrm{Oct}$ & $7 \mathrm{Oct}$ & $\begin{array}{l}\text { Gregory (MS); N02006 (S); Perry } \\
\text { (MR); VA 98R (MS); N96076L (R) }\end{array}$ \\
\hline Northampton Co. & 16 May & $28 \mathrm{Jul}$ & 6 weeks & $29 \mathrm{Sep}$ & $7 \mathrm{Oct}$ & $\begin{array}{l}\text { Gregory (MS); N02006 (S); } \\
\text { Perry (MR); VA 98R (MS) }\end{array}$ \\
\hline \multicolumn{7}{|r|}{ - } \\
\hline Bertie Co. & 5 May & $25 \mathrm{Jul}$ & 10 weeks & 3 Oct & 17 Oct & $\begin{array}{l}\text { Gregory (MS); N02006 (S); Perry } \\
\text { (MR); VA 98R (MS); N03081T (R) }\end{array}$ \\
\hline Bertie Co. (fungicide trial) & 5 May & $25 \mathrm{Jul}$ & 10 weeks & 3 Oct & 17 Oct & NC-V $11(\mathrm{~S})$ \\
\hline Northampton Co. & 16 May & $25 \mathrm{Jul}$ & 10 weeks & 14 Oct & 31 Oct & $\begin{array}{l}\text { Gregory (MS); N02006 (S); Perry } \\
\text { (MR); VA 98R (MS); N03081T (R) }\end{array}$ \\
\hline
\end{tabular}

a Fields located in Northampton County were strip-tilled; all other locations were conventionally tilled.

${ }^{\mathrm{b}}$ Letter abbreviations indicate the level of partial resistance to Sclerotinia minor infection according to the annual North Carolina Peanut Information manual. Abbreviations are as follows: VS = very susceptible; $\mathrm{S}=$ susceptible; $\mathrm{MS}=$ moderately susceptible; $\mathrm{MR}=$ moderately resistant; $\mathrm{R}=$ resistant. 
fungicide. The experimental design in these experiments was a randomized complete block with four to six replicates depending on the year.

In 2004, the Northampton County site received fluazinam ( $0.87 \mathrm{~kg}$ a.i./ha) on an advisory (modified Virginia advisory) or calendar-based schedule, or no fungicide. In 2005, fungicide was applied at a rate of $0.58 \mathrm{~kg}$ a.i./ha using an early iteration of the disease prediction model or calendarbased schedule, or no fungicide. Treatments were limited to three applications per plot for the entire season. These trials were factorial experiments with cultivars (different levels of partial resistance) and fungicide application as the interacting factors. Experimental design was a splitplot design with cultivars as whole plots in a randomized complete block design with six replicates and fungicide application as subplots.

Disease evaluations. In all years, fields were scouted starting in late June, and weekly or biweekly ratings began when disease was first observed at each location (Table 1). The center two rows for each plot were parted by hand, and individual plants with signs of $S$. minor and/or symptoms of Sclerotinia blight were carefully identified and marked with surveyor's flags. Therefore, infected plants were only counted once for the entire season, resulting in a measure of weekly incremental disease incidence (number of newly infected plants each week). In all years, peanuts were dug in late September or early October and harvested throughout the month of October (Table 1). Samples were dried and pod yields were determined.

Weather data collection. Weather data were modeled hourly in all years using the SkyBit service by ZedX, Inc. (Bellafonte, PA). In 2003, weather data were collected on-site and logged with a CR10X micrologger (Campbell Scientific, Logan, UT) at the Perquimans County field. Leaf wetness sensors (Campbell Scientific) were placed at $42-\mathrm{cm}$ height, near the top of the mature canopy. The 15 unpainted sensors were placed in five canopy positions corresponding to top, middle left side (north), middle right side (south), middle, and bottom of the canopy. Each sensor position was replicated three times. Rain was measured with a tipping bucket rain gauge (TE525, Texas Electronics, Dallas, TX). Wind speed, solar and net radiation were measured at the 3-m level with a wind set (Wind Sentry, R.M. Young, Traverse City, MI), Li 200x pyranometer (Li 200x, Li-Cor, Lincoln, NE), and a net radiometer (Q-7.1, REBS, Seattle, WA). Net radiation was also collected just below canopy level, allowing canopy net radiation to be calculated from the difference in the two heights. Air temperature and relative humidity were measured with four sensors (HMP35C, Campbell Scientific) 1 $\mathrm{m}$ above the canopy, at the top of the can- opy, mid-canopy height, and at the bottom of the canopy. Soil temperature sensors were placed at depths of 2.5 and $20 \mathrm{~cm}$. Soil flux sensors were placed at a depth of $5 \mathrm{~cm}$. In 2004, a commercial automated weather station (WatchDog model 700, Spectrum Technologies, Inc., Plainfield, IL, 3340WD) was placed at the Perquimans County field site. Wind speed and direction, relative humidity, dew point, rain, and air temperature were all recorded using the on-board station sensors. Wind variables were recorded at a height of 2.0 $\mathrm{m}$, while all other on-board variables were recorded at $1.8 \mathrm{~m}$. Additional sensors were included to monitor soil moisture (one sensor, watermark soil moisture sensor, Spectrum Technologies, SM6450WD) at a depth of $10 \mathrm{~cm}$, soil temperature (one sensor, external soil temperature sensor, Spectrum Technologies, TEMP3667) at a depth of $10 \mathrm{~cm}$, and leaf wetness (one unpainted leaf wetness sensor, Spectrum Technologies, LW3666) at a height of $42 \mathrm{~cm}$ from the soil surface.

Model derivation. The set of modeled weather data from ZedX included air temperature, leaf wetness, precipitation, relative humidity, soil moisture, and soil temperature. The daily means, maximums, and minimums of each of those variables were calculated. In addition, mean air temperature during leaf wetness and hours of continuous leaf wetness per day were calculated. The 5-day moving averages for the modeled weather variables were calculated for each variable based on procedures in previous studies $(5,15,20)$. All analyses were conducted using SAS v. 8.0 (SAS Institute, Cary, NC) procedures. The weather variables analyzed were: mean, maximum, and minimum air temperature $\left({ }^{\circ} \mathrm{C}\right)$; mean, maximum, and minimum leaf wetness (unitless); temperature during leaf wetness $\left({ }^{\circ} \mathrm{C}\right)$; leaf wetness hours (h); total, mean, and maximum precipitation $(\mathrm{mm})$; mean, maximum, and minimum relative humidity $(\%)$; and soil temperature $\left({ }^{\circ} \mathrm{C}\right)$ and moisture (\%). Pearson correlation coefficients (PROC CORR of SAS statistical software) were calculated for the modeled and recorded on-site hourly weather data from 19 July to 17 September 2003 and 20 June to 8 September 2004 for the Perquimans County sites to confirm accuracy of the modeled weather data.

Only data from plots not receiving fungicides were used to develop the disease prediction model. Incremental disease incidence was standardized among all sites and years by dividing the percentage (using three plants per $0.3 \mathrm{~m}$ of row as the base plant population) of diseased plants for each observation by the number of days between ratings. Initial disease incidence observations for each epidemic were divided by 6 days. Cultivars were then assigned to one of two groups based on resistance. The cultivars and breeding line considered susceptible (NC 12C, Gregory, and N02006), as determined from our data and previous results (T. G. Isleib, unpublished data), were assigned the numeral one for a new parameter called resistance type. The moderately resistant cultivars (Perry, VA 98R, NC-V 11) and the resistant breeding line (N03081T) were assigned a resistance type parameter of zero. Observations using the highly resistant germplasm line, N96076L, were removed from the data set because incidence of disease in that line was very minimal as compared to all other cultivars. Results of a principal components analysis (PROC PRINCOMP of SAS statistical software) of standardized incremental disease incidence and the moving averages of weather variables for weeks 1 though 10 of the epidemics were used to select variables to input in an $R$ square analysis (PROC RSQUARE of SAS statistical software) with Mallows CP statistic (CP option) to describe standardized incremental disease incidence. Plots of $p^{\prime}$ (number of parameters in the model + intercept) versus Mallows CP and $p^{\prime}$ versus $1-R^{2}$ also were used as aids to identify the best-fitting model to describe standardized incremental disease incidence (24). A general linear models procedure (PROC GLM of SAS statistical software) was used to obtain parameter estimates and to test for significance of quadratic and interaction terms. In addition, full and reduced model testing as described by Rawlings et al. (24) was used to test for significant differences in intercepts and weather parameters with and without the resistance type parameter in a model that best described standardized incremental disease incidence in all years. Briefly, this was performed using the resistance type parameter in the full model. Dummy variables were generated for each weather parameter by resistance type interaction, and the significance of each dummy variable was assessed by inclusion and exclusion from the model. Assumptions of least-squares regression were tested via plots of predicted standardized incremental disease incidence versus Studentized residuals for all sites, in all years. Examination of residual plots indicated that it was necessary to transform standardized incremental disease incidence using a square root in order to normalize the data. Transformed standardized incremental disease incidence was designated the Sclerotinia blight disease index. Putative outliers were tested for significance using $t$ tests of the Studentized residuals as described by Rawlings et al. (24). To evaluate the biological validity of the model, the performance of each parameter was examined graphically while all other parameters were held constant at the observed mean for that parameter (data not shown).

Effect of resistance on disease progress. Weekly cumulative disease incidence (\% CDI) was determined for each plot for each Julian day on which data 
were collected. Julian days were then scaled to the minimum Julian day (day 182) that an epidemic was initiated for years and sites in which weather was favorable for high levels of disease (all sites in 2002 and 2003; Perquimans County and Bertie County, 2004) such that time was measured in days from the onset of the earliest epidemic, $T_{a}$. Regressions of CDI as the dependent variable and $T_{a}$, resistance type by fungicide application (no fungicide or full rate application of fungicide) as the independent variable were conducted with the general linear model procedure (PROC GLM of SAS statistical software). Full and reduced model testing were used as in the procedures above to determine parameter estimates, to test for significant differences in slopes and intercepts for each resistance type and fungicide application combination, and to investigate linear and quadratic terms in a model that best described CDI in all years. Transformations using logistic and monomolecular growth functions were also investigated.

\section{RESULTS}

Field studies. Weather in 2002, 2003, and 2004 was cool and wet with high humidity; weather in 2005 was hot and much drier with lower levels of humidity (Fig. 1). Overall levels of disease were lower in 2005 relative to other years (Fig. 2). At all sites where several cultivars were grown, trends in untransformed incremental disease incidence were consistent regardless of resistance level, but the magnitude of incremental disease incidence varied by cultivar (Fig. 2). Disease was first observed on 12 July 2002 (Perquimans County) and on 21 July 2003 (Perquimans and Chowan counties). Untransformed incremental increases in disease incidence in 2002 were low (except week 2) until week 9 (6 September), when incremental disease incidence ranged from 4 to $10 \%$ until harvest (Fig. 2A). In 2003, consistent increases in the magnitude of untransformed incremental disease incidence at the Perquimans County site were recorded on both cultivars throughout the season (Fig. 2B). Hurricane Isabel ravaged the field on 17 September 2003. Plants were not killed, but main stems lodged to the soil surface, thereby eliminating the plant canopy necessary for further disease development. No rating was possible after week 9. At the Chowan County site, the magnitude of untransformed incremental disease incidence was small until week 7 (15 September), when the percentage of newly infected plants ranged from 2 to $4 \%$ (Fig. 2C). At both Bertie County trials in 2004 , disease was first observed on 8 July, and untransformed incremental disease incidence was moderate throughout the season (Fig. 2D and E). In Perquimans County in 2004, disease was first observed on 30 June and untransformed incremental disease incidence was initially high (10\% on the breeding line N02006), then tapered off and remained moderate for the remainder of the season (Fig. 2F). In Northampton County in 2004, onset of disease did not occur until 28 July (much later than at other sites), and untransformed incremental disease incidence was very low until week 4 when untransformed incremental disease incidence ranged from 2 to $4 \%$ (Fig. 2G). Subsequent magnitudes of untransformed incremental disease incidence were low for the remainder of the season (Fig. 2G). Disease was first observed on 25 July at both Bertie County trials in 2005 (Fig. 2H and I). Incremental disease incidence levels were low to moderate in these trials as compared to other years (Fig. 2H and I). In Northampton County in 2005, disease was first observed on 22 August and was low in relation to other trials in other years (Fig. 2J).

Model derivation. Pearson correlation coefficients for the comparison of predicted and actual leaf wetness were $0.15(P$ $<0.0001, n=1,450)$ in 2003 and $0.08(P<$ $0.03, n=668)$ in 2004 for the Perquimans County site. Pearson correlation coefficients for predicted and actual precipitation comparisons were $0.21(P<0.0001, n$ $=1,450)$ in 2003 and $0.20(P<0.20, n=$ $668)$ in 2004 for the Perquimans County site. The low correlation between modeled and observed data for these variables suggested that modeled leaf wetness and precipitation measurements were not accurate, and all leaf wetness and precipitation variables for all locations were subsequently dropped from the data set. Mean air temperature during leaf wetness and hours of leaf wetness also were removed from the data set because they were derived from predicted leaf wetness described above. Percent soil moisture was removed from the entire data set because soils can vary widely from one location to the next in eastern North Carolina and interpolation of this weather variable remotely is limited. In 2004, correlation coefficients for modeled variables of air temperature $(0.97, P<$ $0.0001, n=1,000)$, relative humidity $(0.94$, $P<0.0001, n=1,000)$, and soil temperature $(0.89, P<0.0001, n=1,000)$ were considered sufficiently and positively correlated with their respective on-site parameters and were left in the data set.

Five principal components accounted for approximately $99 \%$ of the variability in the data set (Table 2). Based on the results of the principal components analysis, 5day moving averages of nine variables were selected for $R$-square analysis using only observations made prior to $15 \mathrm{Sep}-$ tember for each site. The variables included the following: mean, maximum, and minimum air temperature; mean, maximum, and minimum relative humidity; mean, maximum, and minimum soil temperature; and quadratic terms for each of these variables, for a total of 18 vari- ables in the working set. Initially, the best model without over parameterization as identified by plots of $p^{\prime}$ versus CP and $1-R^{2}$ was a 12-parameter model $\left(R^{2}=0.38\right.$, Mallows $\mathrm{CP}=14.88$ ) that included mean relative humidity $(\mathrm{RH})$, mean soil temperature (ST), maximum air temperature (MXAT), maximum relative humidity (MXRH), minimum air temperature (MNAT), minimum relative humidity (MNRH), and quadratic terms for each of these six variables. The general linear model procedure (PROC GLM of SAS statistical software) was applied and Studentized residual plots were examined. The $t$ tests of the residuals revealed six observations that were significantly $(P \leq$ 0.01 ) outside the range of the data set, which were deleted. The remaining data were again subjected to the same process. A new 13-parameter model was identified $\left(R^{2}=0.48\right.$, Mallows $\left.\mathrm{CP}=17.28\right)$ that included mean relative humidity, maximum air temperature, maximum relative humidity, minimum air temperature, minimum relative humidity, minimum soil temperature (MNST), and quadratic terms for each of these six variables and that for mean soil temperature. The $t$ test of Studentized residuals identified one additional significant $(P \leq 0.01)$ outlier in the data, which were deleted from subsequent analyses. A final iteration of the above process was performed identifying a 13-parameter model as the best fit without over parameterization. Additional tests of full versus reduced models found no significant differences $(P \leq 0.05)$ between models accounting for separate intercept, slope, and weather variables based on resistance type (24). A reduced model using a single intercept and slope, with one set of weather variables for all resistance types, and 196 total independent observations of Sclerotinia blight disease index values was adopted. The Sclerotinia blight disease index was described using various generated parameters of only air temperature, soil temperature, and relative humidity. The resulting regression model was as follows: Sclerotinia blight disease index = $-34.0170-0.5782 \mathrm{RH}+0.0034 \mathrm{RH}^{2}-$ $0.0168 \mathrm{ST}^{2}-1.1686 \mathrm{MXAT}+0.0251$ MXAT $^{2}+1.4594$ MXRH -0.0075 $\mathrm{MXRH}^{2}-1.2320 \mathrm{MNAT}+0.0452 \mathrm{MNAT}^{2}$ $+0.2907 \mathrm{MNRH}-0.0025 \mathrm{MNRH}^{2}+$ 1.0144 MNST $-0.0259 \mathrm{MNST}^{2} ; P<$ $0.0001, R^{2}=0.50, \mathrm{CV}=46.75$. All weather variables contributed to the model at $P \leq$ 0.02 . The model conformed to the assumptions of least-squares regression, based on the plot of predicted Sclerotinia blight disease index versus Studentized residuals (Fig. 3). Validation of model parameters indicated that highest levels of Sclerotinia blight were predicted when the 5-day average of minimum air temperature was greater than $20^{\circ} \mathrm{C}$ and that for maximum air temperature was greater than $30^{\circ} \mathrm{C}$ (data not shown). Highest levels of Scle- 
rotinia blight were predicted when 5-day averages of mean soil temperature and minimum soil temperatures were moderate (20 to $25^{\circ} \mathrm{C}$ ) (data not shown). Impacts of air and soil temperature tended to offset one another. Predicted Sclerotinia blight disease index values also were greatest when 5-day averages of mean relative humidity increased above $85 \%$ (data not shown).

Incorporation of resistance. Resistance to Sclerotinia blight functioned by reduc- ing the rate of increase in cumulative disease across the three growing seasons favorable for disease (Fig. 4). Slopes and intercepts for all combinations of cultivar resistance type and fungicide treatment were generated. Full and reduced model
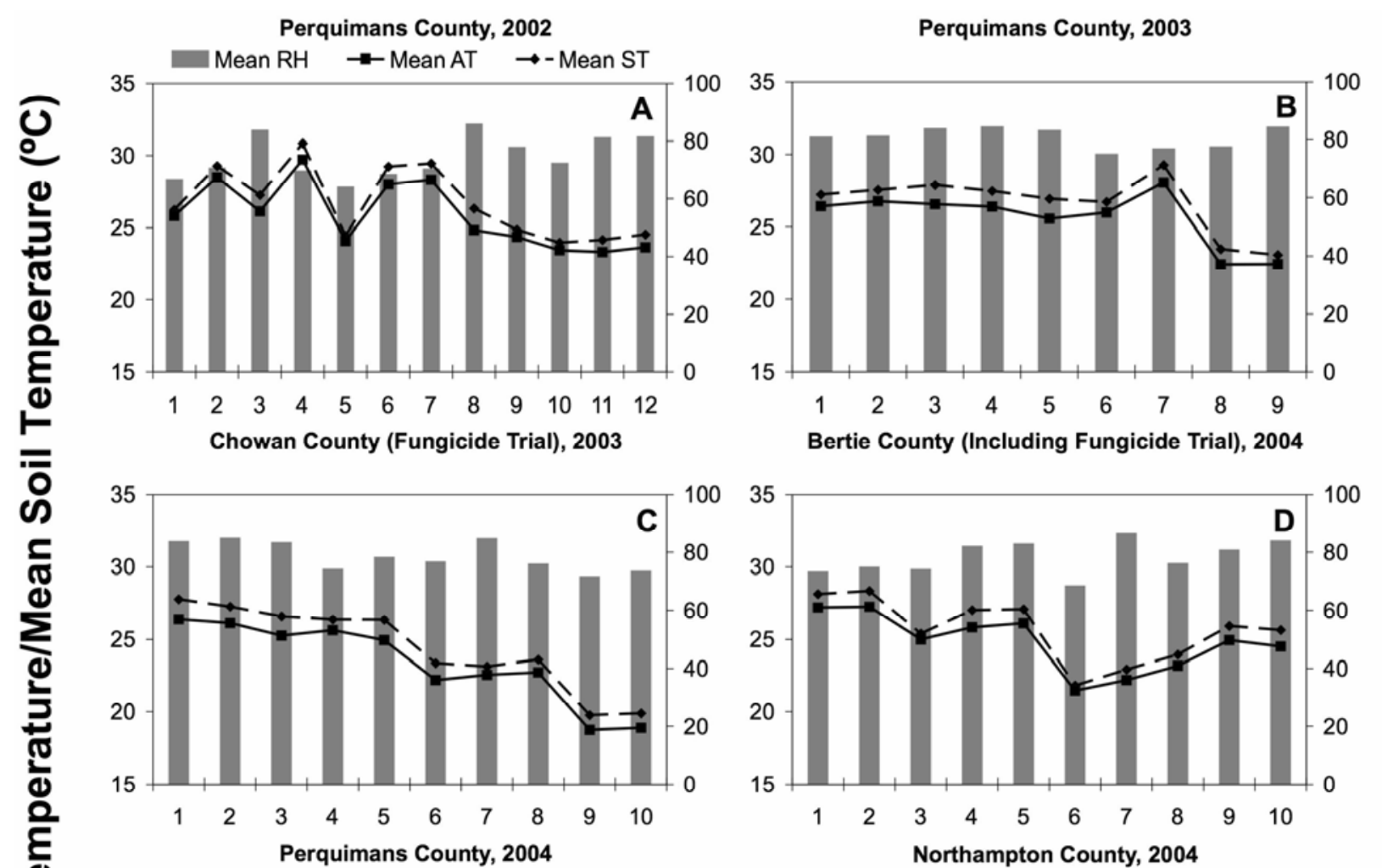

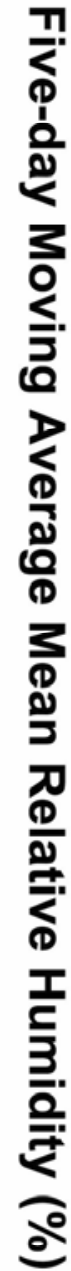

Bertie County (Including Fungicide Trial), 2005

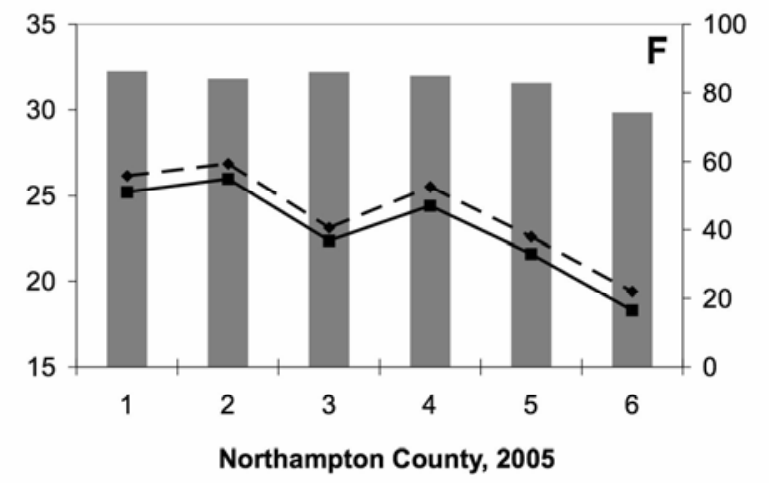

Dे
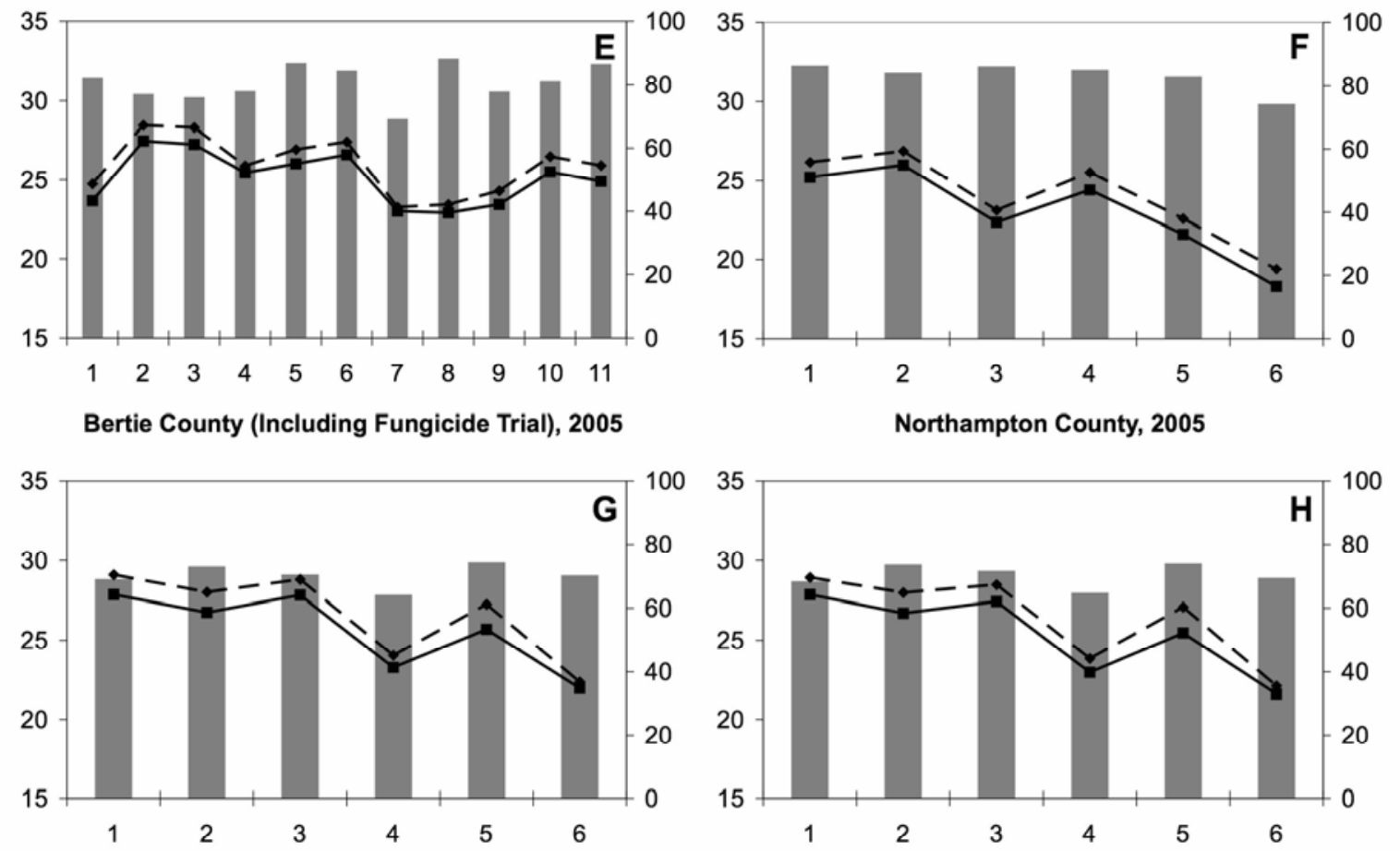

Week During Rating

Fig. 1. Five-day moving averages of the modeled weather variables mean relative humidity (Mean RH), mean air temperature (Mean AT), and mean soil temperature (Mean ST) for the entire disease rating period for Sclerotinia blight trials in four North Carolina counties over four growing seasons. A, Perquimans County, 2002. B, Perquimans County, 2003. C, Chowan County (fungicide trial), 2003. D, Bertie County (including fungicide trial), 2004. E, Perquimans County, 2004. F, Northampton County, 2004. G, Bertie County (including fungicide trial), 2005. H, Northampton County, 2005. 

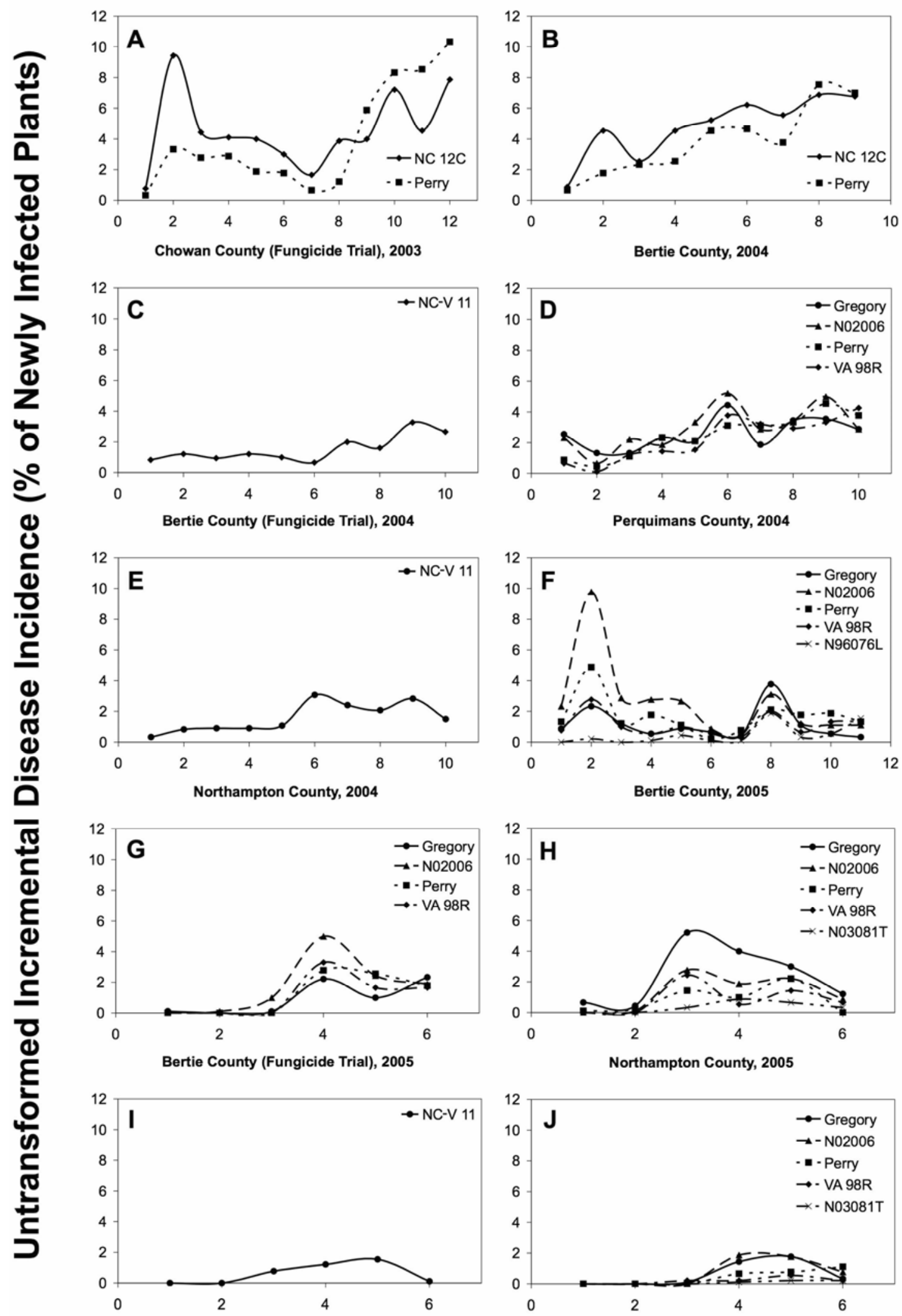

Week During Rating

Fig. 2. Weekly incremental increase in disease incidence (\% newly infected plants) of Sclerotinia blight in grower fields located in four North Carolina counties over four growing seasons. Plots were not treated with fungicide to control Sclerotinia blight. Epidemic duration ranged from 6 to 12 weeks. A, Perquimans County, 2002. B, Perquimans County, 2003. C, Chowan County (fungicide trial), 2002. D, Bertie County, 2004. E, Bertie County (fungicide trial), 2004. F, Perquimans County, 2004. G, Northampton County, 2004. H, Bertie County, 2005. I, Bertie County (fungicide trial), 2005. J, Northampton County, 2005. 
testing of disease progress curves indicated that there was no significant difference $(P$ $\leq 0.05)$ in intercepts of the disease progress curves for the four combinations of resistance type and fungicide application. In contrast, rate of disease progress (slopes) for all treatment combinations differed significantly $(P<0.0001)$ with the exception of resistant cultivars with no fungicide applied and susceptible cultivars with fungicide applied $(P<0.3451)$ (Fig. 4). Transformation of cumulative disease incidence $(\% \mathrm{CDI})$ for the model describing all combinations of treatment using the logistic $\left(R^{2}=0.62, \mathrm{CV}=-23.03\right)$ and monomolecular $\left(R^{2}=0.60, \mathrm{CV}=36.18\right)$ growth functions offered no improvement over linear functions $\left(R^{2}=0.62, \mathrm{CV}=\right.$ 55.64). Addition of quadratic terms to the model $\left(R^{2}=0.64, \mathrm{CV}=54.44\right)$ also offered little improvement over only linear functions. Studentized residuals indicated good fit of the linear models when disease levels were low, while at higher disease levels some lack of fit was identified. The linear regression equations were as follows:

$\% \mathrm{CDI}_{\text {(Resistant cultivars w/ fungicide) }}=0.05+0.13 T_{a}$

$\% \mathrm{CDI}_{\text {(Susceptible cultivars w/ fungicide) }}=0.05+0.23 T_{a}$

$\% \mathrm{CDI}_{\text {(Resistant cultivars w/ no fungicide) }}=0.05+0.25 T_{a}$

$\% \mathrm{CDI}_{\text {(Susceptible cultivars w/ no fungicide) }}=0.05+0.43 T_{a}$

$P<0.0001, R^{2}=0.62, \mathrm{CV}=55.64$, where $T_{a}$ is the time in days after disease onset.

\section{DISCUSSION}

Our Sclerotinia blight regression model may help improve current disease advisory systems. The weather variables we used are easy to measure and can be manipulated using widely available computer software. Our field research marks the first documented use of site-specific, modeled weather data in a Sclerotinia blight model. Using modeled weather data to generate Sclerotinia and other disease advisories would eliminate the need to place individual weather stations throughout peanut growing areas, while providing much more site-specific (localized) information than has been previously available with networked automated weather stations. Use of site-specific weather data also opens the possibility of using weather forecasting models to improve long-term disease advisories (e.g., 5- to 7-day disease forecasts). This can help improve adoption of disease advisory systems by growers who may not find them appealing due to lack of forecasting ability in earlier versions (17).

Our final regression equation explained $50 \%$ of the variability in the 4-year data set. Clustering of inoculum in soil probably was an important source of variability that was not accounted for in the model. Clustering of the inoculum also may explain the occurrence of several outlier observations in the data set that were identified from the Studentized residual plots. Our ability to account for aggregation of inoculum is limited because the currently accepted soil assay technique is too cum- bersome and time-consuming for routine use $(23,28)$. In the future, improvement in soil assay techniques may aid in the development of more accurate models by accounting for aggregation of sclerotia in test plots or grower fields.

In many plant pathosystems, leaf wetness is considered one of the most important weather-related variables in influencing the occurrence of disease (3). We included leaf wetness in our data set, but found that predicted leaf wetness as modeled by SkyBit was not well correlated to on-site leaf wetness. Other researchers have also documented inaccuracy in leaf wetness as estimated by SkyBit and elected not to use this weather variable in analyses $(6,14)$.

Our analyses show that air and soil temperature play a major role in development

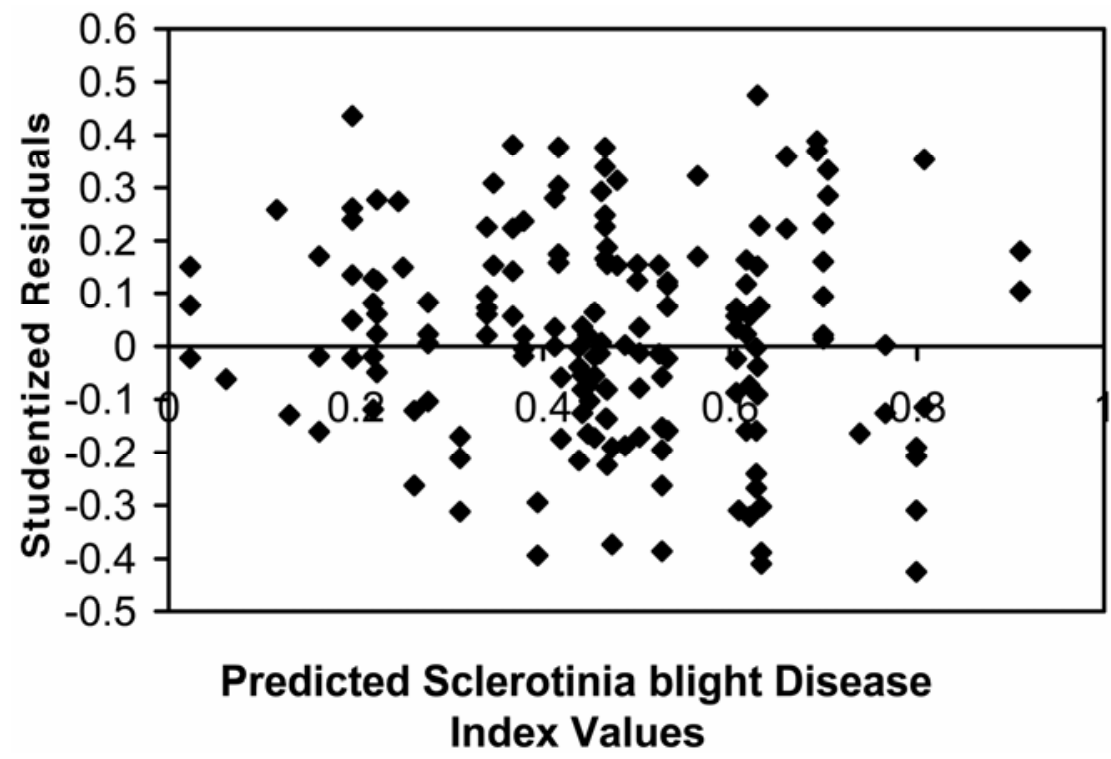

Fig. 3. Predicted Sclerotinia blight disease index values versus Studentized residuals for the model Sclerotinia blight disease index $=-34.0170-0.5782 \mathrm{RH}+0.0034 \mathrm{RH}^{2}-0.0168 \mathrm{ST}^{2}-1.1686 \mathrm{MXAT}$ $+0.0251 \mathrm{MXAT}^{2}+1.4594 \mathrm{MXRH}-0.0075 \mathrm{MXRH}^{2}-1.2320 \mathrm{MNAT}+0.0452 \mathrm{MNAT}^{2}+0.2907$ $\mathrm{MNRH}-0.0025 \mathrm{MNRH}^{2}+1.0144 \mathrm{MNST}-0.0259 \mathrm{MNST}^{2} ; P<0.0001, R^{2}=0.50, \mathrm{CV}=46.75$, where the Sclerotinia blight disease index is the square root transformation of the percentage of daily infected plants in research plots in grower fields located in four North Carolina counties over four growing seasons. Plots were not treated with fungicide to control Sclerotinia blight. Epidemic duration ranged from 6 to 12 weeks depending on location and environment.

Table 2. Principal components analysis of contribution of weather variables modeled for grower fields to variability in Sclerotinia blight incidence in three North Carolina counties over four growing seasons

\begin{tabular}{|c|c|c|c|c|c|}
\hline Parameter $^{\mathbf{a}}$ & Factor 1 & Factor 2 & Factor 3 & Factor 4 & Factor 5 \\
\hline Incremental disease incidence $(\%)$ & -0.0849 & 0.1156 & 0.9770 & -0.1570 & 0.0070 \\
\hline Mean air temperature $\left({ }^{\circ} \mathrm{C}\right)$ & 0.4231 & 0.0749 & 0.0404 & 0.0875 & 0.2061 \\
\hline Mean relative humidity (\%) & -0.0797 & 0.5523 & -0.0814 & -0.0214 & 0.2343 \\
\hline Mean soil temperature $\left({ }^{\circ} \mathrm{C}\right)$ & 0.4242 & 0.0879 & 0.0284 & 0.0463 & 0.0617 \\
\hline Maximum air temperature $\left({ }^{\circ} \mathrm{C}\right)$ & 0.4082 & -0.1400 & 0.0934 & 0.2487 & 0.1101 \\
\hline Maximum relative humidity (\%) & -0.1421 & 0.4502 & 0.0656 & 0.7944 & 0.3048 \\
\hline Maximum soil temperature $\left({ }^{\circ} \mathrm{C}\right)$ & 0.4162 & -0.1067 & 0.0797 & 0.2147 & 0.0950 \\
\hline Minimum air temperature $\left({ }^{\circ} \mathrm{C}\right)$ & 0.3679 & 0.2825 & -0.0168 & -0.1252 & 0.2343 \\
\hline Minimum relative humidity (\%) & -0.0759 & 0.5419 & -0.1190 & -0.2910 & 0.2687 \\
\hline Minimum soil temperature $\left({ }^{\circ} \mathrm{C}\right)$ & 0.3550 & 0.2468 & -0.0495 & -0.3541 & 0.8108 \\
\hline Eigenvalue & 5.4012 & 3.0968 & 0.9532 & 0.3915 & 0.1196 \\
\hline Proportion & 0.5401 & 0.3097 & 0.0953 & 0.0392 & 0.0120 \\
\hline Cumulative & 0.5401 & 0.8498 & 0.9451 & 0.9843 & 0.9962 \\
\hline
\end{tabular}

a Data analyzed were moving 5-day averages of the variables indicated. Disease incidence data were taken from plots with no fungicide application. 
of Sclerotinia blight, and are supported by the use of these variables in the PhippsLangston advisory (15) and studies conducted under controlled conditions (25). In the Phipps-Langston advisory, air and soil temperature are treated interchangeably, where the temperature variable that results in the "highest index" is used (15). In our studies, air and soil temperature were treated separately. Although these two variables are related, they should be considered independently since they can have very different effects on the biology of the fungus as shown in other studies. Recent in vitro investigation of environmental influences on the epidemiology of $S$. minor showed that high soil and air temperature $\left(30^{\circ} \mathrm{C}\right)$ were favorable for germination of sclerotia of the fungus (25). Furthermore, in the field, air and soil temperature can fluctuate in unison, but magnitude of these variables can differ dramatically during certain times of the year (Fig. 1). Late in the growing season and during the night, periods of high soil temperature relative to the cooler air temperatures and high relative humidity can provide an environment highly conducive for the growth of $\mathrm{S}$. $\mathrm{mi}$ nor. This situation was apparent in our field trials when there were rapid incremental increases in Sclerotinia blight late in September and October. Our analyses during development of the disease regression model also indicated the importance of including both temperature variables. All models investigated included a form of both air and soil temperature parameters, and both were considered highly influen- tial parameters. Treating these two temperature effects separately will make the regression model much more accurate and complex at the same time. However, with the widespread availability of high-speed computing power, the increased accuracy of predictions is worth the trade-off in complexity.

The influence of humidity in our disease regression model and the disease advisory currently being used in North Carolina were similar. In our regression model, 5day moving averages of mean relative humidity of $85 \%$ or higher were favorable for Sclerotinia blight. Langston et al. (15) predicted the greatest risk of Sclerotinia blight when relative humidity was greater than $95 \%$ for $\geq 8 \mathrm{~h}$ consecutively on the previous day. In addition, germination and growth of the fungus was reported most favorable at relative humidity of $\geq 95 \%$ $(4,19)$ or when soil moisture was sufficient to maintain high humidity above the soil surface (25). In the Phipps-Langston advisory, rainfall of $\geq 1.27 \mathrm{~cm}$ in the previous 5 days can have the same influence on predictions of disease as the relative humidity requirement (15). Our disease regression model does not rely on precipitation because unlike other variables we used, rainfall is often not consistent across locations, making it difficult to interpolate for purposes of site-specific modeling. This is especially true in rural peanut growing regions of North Carolina, where networked automated weather station coverage is sparse, further limiting prediction of rainfall measurements.
We showed that the partial resistance currently available in virginia-type cultivars reduces the rate of increase in cumulative disease incidence over the entire epidemic. Disease models accounting for separate intercepts, slopes, and weather variables based on resistance type were not necessary, indicating that incremental disease incidence changed similarly in response to weather variables on all cultivars and advanced breeding lines tested.

In the Virginia-Carolina peanut production area, the current Phipps-Langston advisory has enabled growers to manage fungicide use, time, and resources much more efficiently and profitably. Improvements to this system could only increase profit and efficiency, and reduce unnecessary dependency on fungicides. A disease advisory based on the regression models presented here would make it possible for growers to integrate several disease control strategies to best protect their peanut crops, save on fungicide sprays, budget time efficiently, and decrease the dependency and associated costs of on-site automated weather stations.

\section{ACKNOWLEDGMENTS}

We thank R. D. Magarey and J. M. Russo for their contributions and expertise in applying modeled weather data for use in our disease prediction model, and M. C. Garrison for field site support.

\section{LITERATURE CITED}

1. Bailey, J. E., Phipps, P. M., Lee, T. A., and Damicone, J. 1993. Utilization of environmental thresholds to minimize fungicide applications for control of Sclerotinia blight of peanut. (Abstr.) Proc. Am. Peanut Res. Ed. Soc. 25:46.

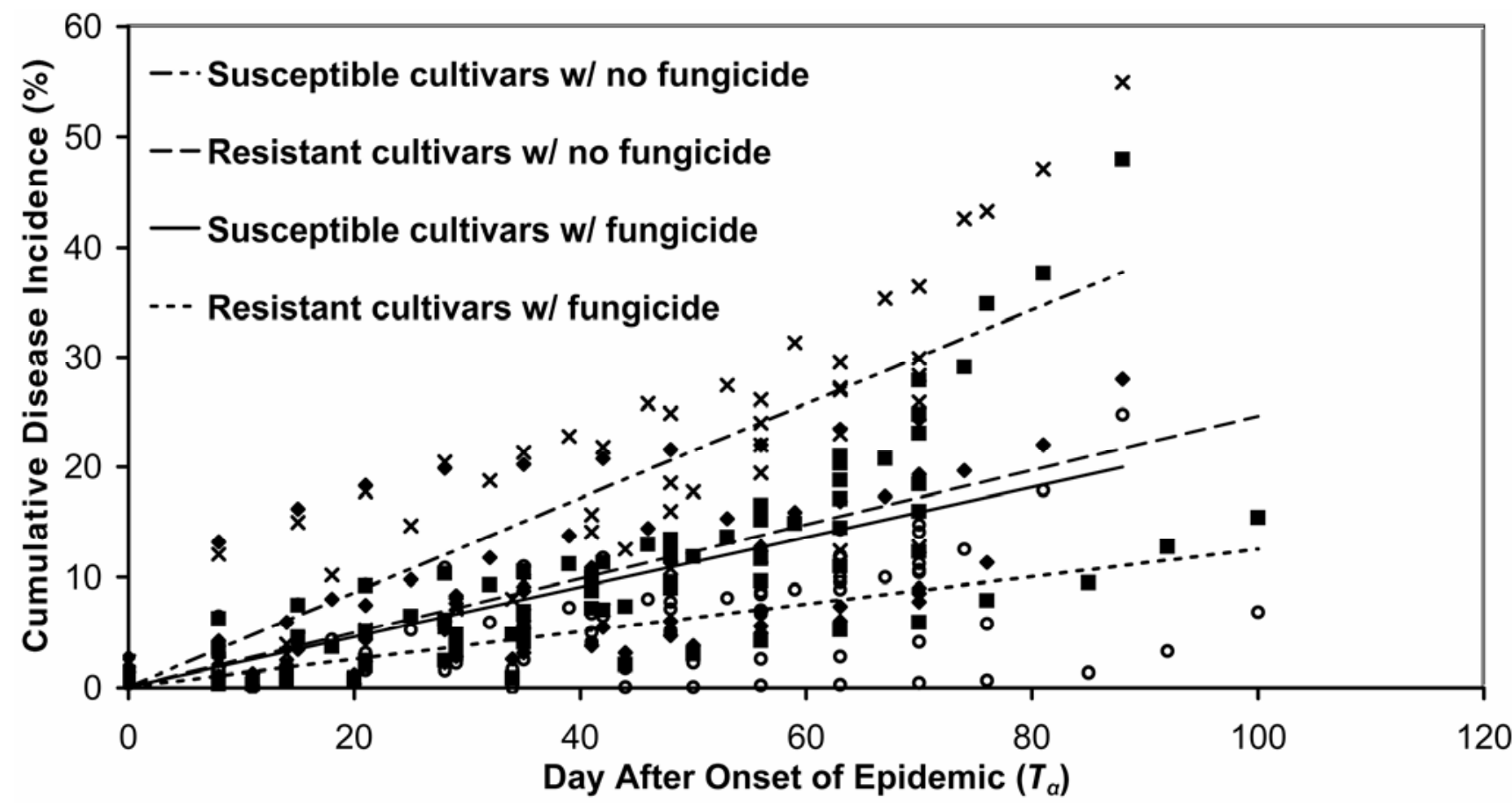

Fig. 4. Time in days after epidemic onset $\left(T_{a}\right)$ versus cumulative disease incidence $(\%)$ for four combinations of cultivar and fungicide application as described by the following linear equations: $\% \mathrm{CDI}_{(\text {Resistant cultivars w/ fungicide) }}=0.05+0.13 T_{a} ; \% \mathrm{CDI}_{(\text {Susceptible cultivars w/ fungicide) }}=0.05+0.23 T_{a} ; \% \mathrm{CDI}_{(\text {Resistant }}$ cultivars $\mathrm{w} /$ no fungicide) $=0.05+0.25 T_{a}$; and $\% \mathrm{CDI}_{\text {(Susceptible cultivars } \mathrm{w} / \text { no fungicide) }}=0.05+0.43 T_{a} ; P<0.0001, R^{2}=0.62, \mathrm{CV}=55.64 . T_{a}$ was scaled to the minimum Julian day (day 182) that disease was observed in all years in the data set. Epidemic duration ranged from 6 to 12 weeks depending on location and environment. 
2. Butzler, T. M., Bailey, J. E., and Beute, M. K. 1993. Effects of pre-inoculation and postinoculation application of fluazinam on Sclerotinia minor using three peanut genotypes. (Abstr.) Proc. Am. Peanut Res. Ed. Soc. 25:19.

3. Campbell, C. L., and Madden, L. V. 1990. Monitoring epidemics: Environment. Pages 43-73 in: Plant Disease Epidemiology. John Wiley \& Sons, New York.

4. Dow, R. L., Porter, D. M., and Powell, N. L. 1988. Effect of environmental factors on Sclerotinia minor and Sclerotinia blight of peanut. Phytopathology 78:672-676.

5. Fidanza, M. A., Dernoeden, P. H., and Grybauskas, A. P. 1996. Development and field validation of a brown patch warning model for perennial ryegrass turf. Phytopathology 86:385-390.

6. Gleason, M. L., Parker, S. K., Pitblado, R. E., Latin, R. X., Speranzini, D., Hazzard, R. V., Maletta, M. J., Cowgill, W. P., Jr., and Bierderstedt, D. L. 1997. Validation of a commercial system for remote estimation of wetness duration. Plant Dis. 81:825-829.

7. Hau, F. C., and Beute, M. K. 1983. Effects of chlorothalonil on the virulence and physiology of nontargeted pathogen, Sclerotinia minor. Phytopathology 73:475-479.

8. Imolehin, E. D., Grogan, R. G., and Duniway, J. M. 1980. Effect of temperature and moisture tension on growth, sclerotial production, germination, and infection by Sclerotinia minor. Phytopathology 70:1153-1157.

9. Isleib, T. G., Rice, P. W., Bailey, J. E., Mozingo, R. W., and Pattee, H. E. 1997. Registation of 'NC 12C' peanut. Crop Sci. 37:1976

10. Isleib, T. G., Rice, P. W., Mozingo, R. W., II, Bailey, J. E., Mozingo, R. W., and Pattee, H. E. 2003. Registration of 'Perry' peanut. Crop Sci. 43:738-739.

11. Isleib, T. G., Rice, P. W., Mozingo, R. W., II, Copeland, S. C., Graeber, J. B., Shew, B. B.,
Smith, D. L., Melouk, H. A., and Stalker, H. T. 2006. Registration of N96076L peanut germplasm. Crop Sci. 46:2329-2330.

12. Isleib, T. G., Rice, P. W., Mozingo, R. W., Mozingo, R. W., II, and Pattee, H. E. 1999. Registration of 'Gregory' peanut. Crop Sci. 39:1526.

13. Jordan, D. L., Spears, J. F., Brandenburg, R. L., Brown, A. B., Shew, B. B., Roberson, G. T., and Bullen, G., eds. 2007. 2007 Peanut Information. N.C. Coop. Ext., Raleigh AG-331.

14. Kim, K. S., Gleason, M. L., and Taylor, S. E. 2006. Forecasting site-specific leaf wetness duration for input to disease-warning systems. Plant Dis. 90:650-656.

15. Langston, D. B., Jr., Phipps, P. M., and Stipes, R. J. 2002. An algorithm for predicting outbreaks of Sclerotinia blight of peanut and improving the timing of fungicide sprays. Plant Dis. 86:118-126.

16. Magarey, R. D., Seem, R. C., Russo, J. M., Zack, J. W., Waight, K. T., Travis, J. W., and Oudemans, P. V. 2001. Site-specific weather information without on-site sensors. Plant Dis. 85:1216-1226.

17. Magarey, R. D., Travis, J. W., Russo, J. M., Seem, R. C., and Magarey, P. A. 2002. Decision support systems: Quenching the thirst. Plant Dis. 86:4-14.

18. Mozingo, R. W., Coffelt, T. A., and Isleib, T. G. 2000. Registration of 'VA 98R' peanut. Crop Sci. 9:848-850.

19. Phipps, P. M. 1995. An assessment of environmental conditions preceding outbreaks of Sclerotinia blight of peanut in Virginia. Peanut Sci. 22:90-93.

20. Phipps, P. M., Deck, S. H., and Walker, D. R. 1997. Weather based crop and disease advisories for peanut in Virginia. Plant Dis. 81:236244.

21. Porter, D. M., and Melouk, H. M. 1997. Sclerotinia blight. Pages 34-35 in: Compendium of
Peanut Diseases, 2nd ed. N. Kokalis-Burelle, D. M. Porter, R. Rodriguez-Kabana, D. H Smith, and P. Subrahmanyam, eds. American Phytopathological Society, St. Paul, MN.

22. Porter, D. M., Smith, D. H., and RodriguezKabana, R. 1982. Peanut plant diseases. Pages 326-410 in: Peanut Science and Technology. H. E. Pattee and C. T. Young, eds. American Peanut Research and Education Society, Yoakum, TX.

23. Porter, D. M., and Steele, J. L. 1983. Quantitative assay by elutriation of peanut field soil for sclerotia of Sclerotinia minor. Phytopathology 73:636-640.

24. Rawlings, J. O., Pantula, S. G., and Dickey, D. A. 2001. Applied Regression Analysis: A Research Tool. Springer, New York.

25. Smith, D. L., Hollowell, J. E., Isleib, T. G., and Shew, B. B. 2006. Analysis of factors that influence the epidemiology of Sclerotinia minor on peanut. Plant Dis. 90:1425-1432.

26. Smith, D. L., Hollowell, J. E., Shew, B. B., and Cochran, A. 2005. Evaluation of alternating fungicide treatments for controlling Sclerotinia blight of peanut, 2004. Fungic. Nematicide Tests 60:FC096.

27. Smith, D. L., Hollowell, J. E., Shew, B. B., and Cochran, A. 2006. Application time and sequence of fungicide treatments for controlling Sclerotinia blight of peanut, 2005. Fungic. Nematicide Tests 61:FC018

28. Subbarao, K. V., Dacuyan, S., Koike, S. T., and Jackson, L. E. 1994. Evaluation of three quantitative assays for Sclerotinia minor. Phytopathology 84:1471-1475.

29. Wymore, L. A., and Lorbeer, J. W. 1987. Effect of cold treatment and drying on mycelial germination by sclerotia of Sclerotinia minor Phytopathology 77:851-856.

30. Wynne, J. C., Coffelt, T. A., Mozingo, R. W., and Anderson, W. F. 1991. Registration of 'NC-V 11' peanut. Crop Sci. 31:484-485. 